\title{
MDM2 SNP309 and risk of endometrial cancer
}

\author{
Stian Knappskog • Per Eystein Lønning
}

Received: 19 May 2014 / Accepted: 16 June 2014 / Published online: 26 June 2014

(C) International Society of Oncology and BioMarkers (ISOBM) 2014

\section{Dear Editor,}

We read with interest the paper "Common variant on $M D M 2$ contributes to endometrial cancer susceptibility: evidence based on 7 studies" by Zhao et al. in Tumor Biology [1].

In this paper, the authors assess the impact of the MDM2 promoter SNP309 (rs2279744) on risk of endometrial cancer by performing a meta-analysis of seven original articles (eight independent case-control designed studies). Based on their findings, the authors conclude that the SNP309Gallele is associated with an increased risk of endometrial cancer, both in an allele contrast model and in a recessive model. Further, the authors find this to be true both among Caucasians and Asians. Most original articles assessing the impact SNP309 on risk of endometrial cancer have so far been small, and it is therefore highly appropriate to perform meta-analyses in order to elucidate the potential role of this MDM2 variant. While the data presented by Zhao et al. are interesting, we would like to make some additional comments.

In their meta-analysis, Zhao et al. included seven original articles, with a total number of 1,278 cases and 2,189 controls, omitting our study from 2012, which is the largest study on SNP309 in endometrial cancer to date [2]. In our study, we included 910 Caucasians diagnosed with endometrial cancer and 2,465 controls. If this data set had been included in the meta-analysis, it would weigh approximately $50 \%$ and, therefore, would have had a major impact on the output, both in the

S. Knappskog $(\bowtie) \cdot$ P. E. Lønning

Section of Oncology, Department of Clinical Science, University of

Bergen, Bergen, Norway

e-mail: stian.knappskog@med.uib.no

S. Knappskog • P. E. Lønning

Department of Oncology, Haukeland University Hospital, Bergen, Norway overall assessments and even more so in the subgroup of Caucasians. Notably, our data set, in addition to being published in our original article [2], was also included in a previous meta-analysis assessing the impact of SNP309 on endometrial cancer risk [3].

We would also like to point out that any study of $M D M 2$ SNP309 in Caucasians has a potential confounding factor that needs to be taken into account/discussed. This relates to a second MDM2 promoter SNP, SNP285G $>C$ (rs117039649). SNP285 is in complete linkage disequilibrium with SNP309. The variant C-allele of SNP285 is present on about $12 \%$ of the SNP309G-alleles in North Western Caucasian populations but absent in East Asian and African populations [4-6]. Importantly, SNP285C has an antagonistic effect against SNP309G: in vitro studies have shown the SNP309Gallele to elongate a binding site for the transcription factor Sp1 and thereby increase MDM2 transcription [4, 7], while the SNP285C-allele reduces Sp1 binding and transcription $[4,8]$. In line with the in vitro findings, case-control studies have shown SNP285C to significantly reduce the risk of ovarian, breast, and endometrial cancer $[2,4]$. Notably, censoring individuals harboring SNP285C from the analyses has been shown to increase the odds ratios related to $\mathrm{SNP} 309 \mathrm{G}$, for endometrial as well as for ovarian cancer $[2,4]$. Thus, any study assessing the impact of SNP309 on cancer risk among Caucasians may probably benefit from correcting for SNP285-status in the cohorts.

Taken together, the data presented by Zhao et al. are interesting and gives insight into the effect of MDM2 SNP309. However, the number of studies assessing the impact of SNP309 on risk of endometrial cancer is low, and larger studies and meta-analyses are required in order to elucidate the effect of SNP309 status, not only on endometrial cancer risk but also on the risk of any cancer form evaluated in this respect. 


\section{References}

1. Zhao Y, Yang X, Hao X, Pan X, Zhao B, Ma J, Fang J, Zhao M: Common variant on $\mathrm{mdm} 2$ contributes to endometrial cancer susceptibility: Evidence based on 7 studies. Tumour biology : the journal of the International Society for Oncodevelopmental Biology and Medicine 2014

2. Knappskog S, Trovik J, Marcickiewicz J, Tingulstad S, Staff AC. MoMa TECsg, Romundstad P, Hveem K, Vatten L, Salvesen HB, Lonning PE: Snp285c modulates oestrogen receptor/sp1 binding to the $\mathrm{mdm} 2$ promoter and reduces the risk of endometrial but not prostatic cancer. Eur J Cancer. 2012;48:1988-96.

3. Peng Q, Mo C, Qin A, Lao X, Chen Z, Sui J, et al. Mdm2 snp309 polymorphism contributes to endometrial cancer susceptibility: evidence from a meta-analysis. Journal Exp Clin Cancer Res : CR. 2013;32:85.

4. Knappskog S, Bjornslett M, Myklebust LM, Huijts PE, Vreeswijk MP, Edvardsen $\mathrm{H}$, et al. The mdm2 promoter snp $285 \mathrm{c} / 309 \mathrm{~g}$ haplotype diminishes sp1 transcription factor binding and reduces risk for breast and ovarian cancer in Caucasians. Cancer Cell. 2011;19:273-82.
5. Knappskog S, Gansmo LB, Dibirova K, Metspalu A, Cybulski C, Peterlongo P, Aaltonen LA, Vatten L, Romundstad P, Hveem K, Devilee P, Evans DG, Lin D, van Camp G, Manolopoulos VG, Osorio A, Milani L, Ozcelik T, Zalloua P, Mouzaya F, Bliznetz E, Balanovska E, Pocheshkova E, Kučinskas V, Atramentova L, Nymadawa P, Titov K, Lavryashina M, Yusupov Y, Bogdanova N, Koshel S, Zamora J, Wedge D, Charlesworth D, Dork T, Balanovsky O, Lonning PE: Population distribution and ancestry of the cancer protective mdm2 snp285 (rs117039649). Oncotarget 2014. http:// www.impactjournals.com/oncotarget/. Accessed 21 June 2014.

6. Knappskog S, Lonning PE. Mdm2 promoter snp285 and snp309; phylogeny and impact on cancer risk. Oncotarget. 2011;2:251-8.

7. Bond GL, Hu W, Bond EE, Robins H, Lutzker SG, Arva NC, et al. A single nucleotide polymorphism in the mdm2 promoter attenuates the p53 tumor suppressor pathway and accelerates tumor formation in humans. Cell. 2004;119:591-602.

8. Wu DW, Lee MC, Wang J, Chen CY, Cheng YW, Lee H. Ddx 3 loss by p53 inactivation promotes tumor malignancy via the $\mathrm{mdm} 2 / \mathrm{slug} / \mathrm{e}-$ cadherin pathway and poor patient outcome in non-small-cell lung cancer. Oncogene. 2014;33:1515-26. 